\title{
Studi Alternatif Perencanaan Pola Operasi Dan Alokasi Air Waduk Titab
}

\author{
I Putu Aldy Pradana Elsaputra, Prof. Dr. Ir. Nadjadji Anwar, M.Sc. \\ Departemen Teknik Sipil, Fakultas Teknik Sipil, Lingkungan dan Kebumian, \\ Institut Teknologi Sepuluh Nopember \\ Jl. Arief Rahman Hakim, Surabaya 60111 Indonesia \\ e-mail : aldypradana111@gmail.com,nadjadji@ce.its.ac.id
}

\begin{abstract}
Abstrak - Waduk Titab terletak di DAS Sungai Saba, kecamatan Busungbiu, Kabupaten Buleleng. Waduk Titab dirancang sebagai penyedia air untuk irigasi, air baku dan Pembangkit Listrik Tenaga Air (PLTA). Waduk ini diharapkan dapat memenuhi kebutuhan masyarakat Buleleng dan sekitarnya sebagai waduk serbaguna sehingga perlu adanya perencanaan operasional waduk yang baik.

Waduk yang rampung pada tahun 2015 ini direncanakan akan beroperasi pada tahun 2016. Namun karena terdapat masalah struktur bada bendungan, pengoperasian diundur sampai tahun 2017. Pada awalnya dari pihak pembangun dari waduk ini sudah menyusun perencanaan pola pengoperasian waduk, akan tetapi penyusunan tersebut dilakukan ketika waduk masih belum selesai dibangun. Maka dari itu direncanakan alternatif pola operasi setelah waduk selesai dibangun sebagai pembanding pola operasi yang telah ada (eksisting).

Dari hasil analisa yang telah dilakukan, didapatkan beberapa kesimpulan yaitu debit inflow waduk diperoleh dari perhitungan debit aliran rendah dengan metode FJ Mock, kemudian dibangkitkan untuk 30 tahun ke depan dengan metode Thomas Fiering. Hasil dari bangkitan debit inflow, debit maksimal sebesar $23,23 \mathrm{~m}^{3} /$ detik dan debit terendah adalah $1,28 \mathrm{~m}^{3} /$ detik. Untuk debit outflow maksimal sebesar 6,24 $\mathrm{m}^{3} /$ detik dan debit terendah sebesar $3,55 \mathrm{~m}^{3} /$ detik. Besar kebutuhan air irigasi maksimum untuk awal masa tanam Nopember I dengan luas daerah irigasi 3589,64 Ha D.I. Saba adalah 3,66 $\mathrm{m}^{3} /$ detik dan untuk daerah irigasi puluran kebutuhan maksimum sebesar $1,02 \mathrm{~m}^{3} /$ detik. Besar kebutuhan air baku untuk tahun 2017-2046 pada keadaan normal adalah sebesar 583,50 lt/dt. Sedangkan besar kebutuhan air baku pada hari maksimum adalah sebesar $671,02 \mathrm{lt} / \mathrm{dt}$. Untuk jam puncak adalah sebesar 1021,12 lt/dt. Besar debit Andalan 80\% yang digunakan adalah sebesar $1.55 \mathrm{~m}^{3} /$ detik untuk perhitungan potensi PLTA dan dapat membangkitkan daya sebesar 0,74 MW, serta energi listrik hingga mencapai 6510,61 MWh. Dan dari hasil perbandingan yang telah dibuat, dapat diketahui bahwa alternatif yang lebih baik adalah perhitungan perencanaan simulasi pola operasi hasil studi. Alasan dari penilaian ini adalah perencanaan hasil studi dilakukan setelah waduk sudah selesai dibangun, sudah dilakukan optimasi kebutuhan air yang diperlukan, dan tingkat keberhasilan waduk dari perencanaan studi yaitu rata-rata sebesar $98,50 \%$ yang mana tingkat keberhasilan tersebut lebih besar dari perencanaan pada eksisting.
\end{abstract}

Kata kunci: Waduk Titab, Operasi, Irigasi, PLTA, Air Baku

\section{PENDAHULUAN}

Air sebagai salah satu sumber daya alam yang mempunyai keterbatasan-keterbatasan dari segi jumlah, ruang maupun waktu. Mengingat keterbatasan tersedianya air tersebut, maka potensi air yang ada harus dimanfaatkan dengan sebaiknya. Untuk dapat merealisasi hal tersebut, diperlukan sarana dan prasarana pendukung yang baik. Dalam hal ini adalah pemanfaatan air secara optimal, diantaranya dengan pembangunan waduk. Dengan adanya waduk maka kelebihan air pada musim hujan dapat ditampung dan dimanfaatkan selama musim kemarau serta dapat sebagai pengendali banjir pada musim penghujan.

Salah satu waduk yang baru selesai dibangun untuk mengatasi permasalahan di atas adalah waduk Titab. Waduk Titab berada di Sungai Saba yang hulunya terletak di Kabupaten Tabanan dan bermuara pada kawasan kegiatan ekonomi di Kecamatan Seririt, Kabupaten Buleleng untuk kebutuhan irigasi masyarakat sekitar. Waduk ini juga direncanakan sebagai waduk tahunan yang dioperasikan sebagai penyuplai ketersediaan air bersih di daerah Buleleng dan sekitarnya, pembangkit tenaga listrik. Agar waduk ini dapat memenuhi kebutuhan masyarakat Buleleng dan sekitarnya sebagai waduk serbaguna, perlu adanya operasional waduk yang baik.

Waduk yang rampung pada tahun 2015 ini direncanakan akan beroperasi pada tahun 2016. Namun karena terdapat masalah struktur bada bendungan, pengoperasian diundur sampai tahun 2017. Pada awalnya dari pihak pembangun dari waduk ini sudah menyusun perencanaan pola pengoperasian waduk, akan tetapi penyusunan tersebut dilakukan ketika waduk masih belum selesai dibangun. Maka dari itu direncanakan alternatif pola operasi setelah waduk selesai dibangun sebagai pembanding pola operasi yang telah ada (eksisting) dan dilakukan optimasi apabila pada perhitungan studi terjadi kekurangan atau kelebihan air. 
JURNAL HIDROTEKNIK Vol. 2, No.2, (2017) ISSN : 2477-3212

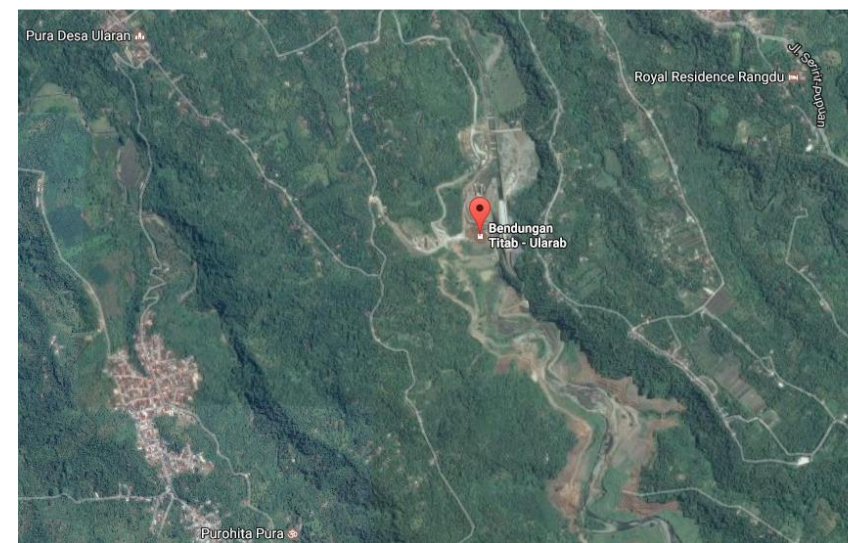

Gambar 1. Peta Lokasi Waduk Titab

\section{II.METODE PENELITIAN}

Metodologi yang digunakan dalam perencanaan ini adalah sebagai berikut :

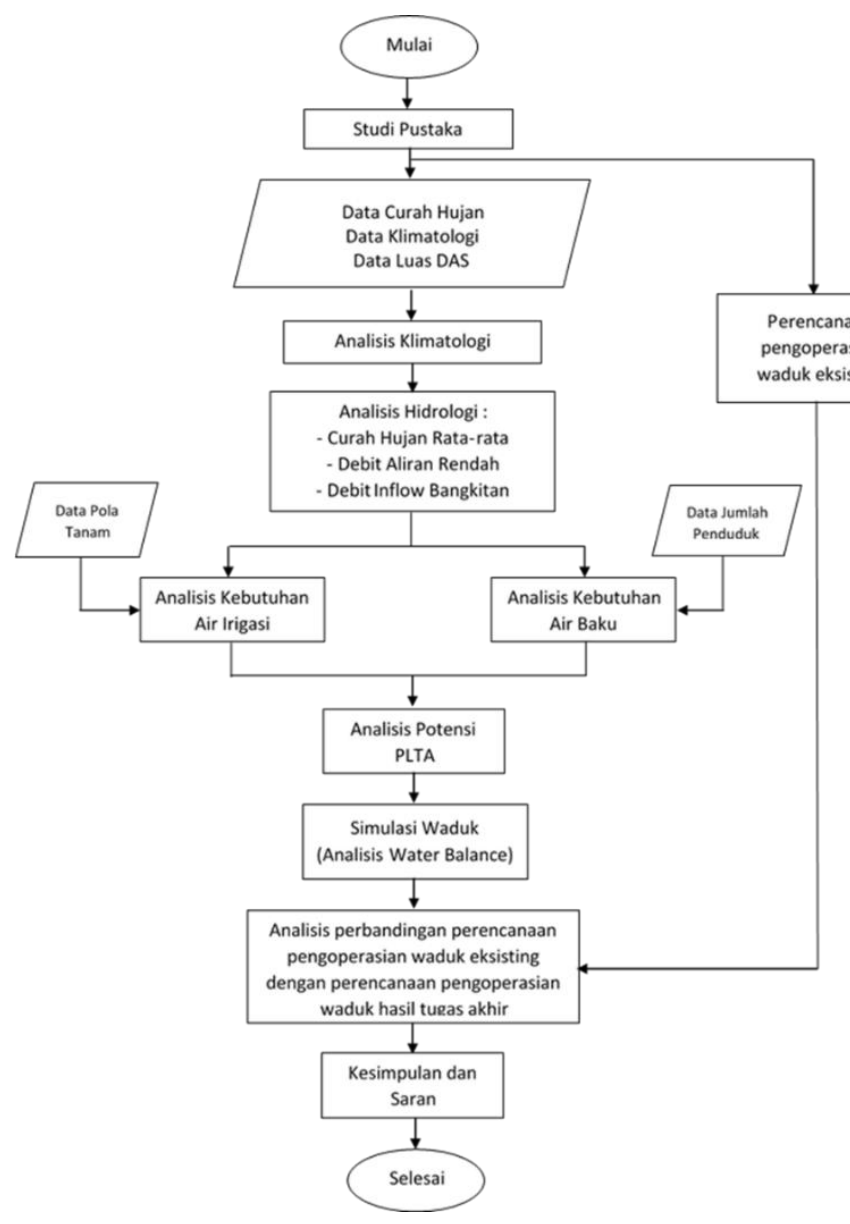

Gambar 2. Diagram Alir Pengerjaan Tugas Akhir

\section{HASIL DAN DISKUSI}

\section{A. Curah Hujan Rata-rata}

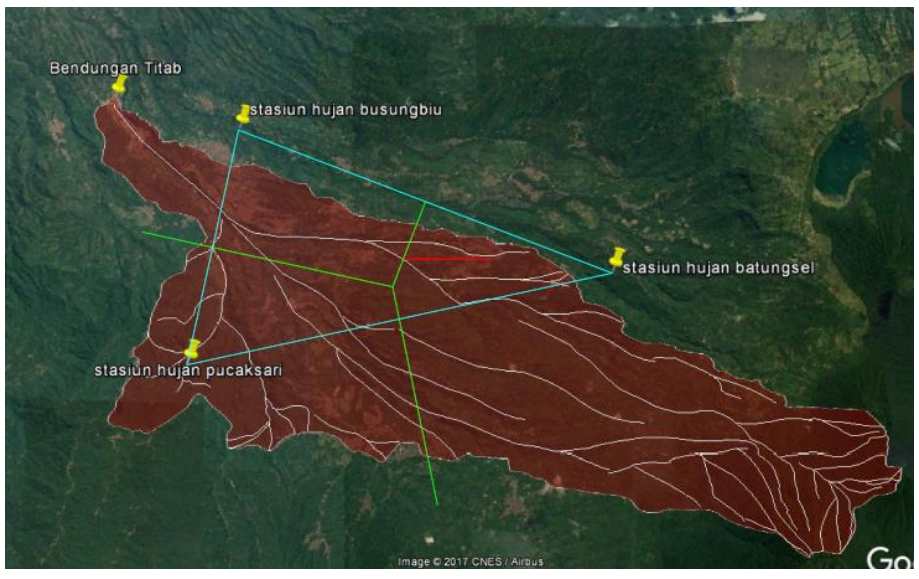

Gambar 3. Luas Daerah Pengaruh Stasiun Hujan Busungbiu, Batungsel,dan Pucaksari

Luas total DAS Waduk Titab adalah $84 \mathrm{~km}^{2}$. Luas daerah pengaruh stasiun Busungbiu sebesar $12.56 \mathrm{~km}^{2}$ sehingga faktor pembobotnya sebesar 0,15 . Luas daerah pengaruh stasiun Batungsel sebesar $46.72 \mathrm{~km}^{2}$ sehingga faktor pembobotnya sebesar 0,56. Luas daerah pengaruh stasiun Pucaksari sebesar $24.72 \mathrm{~km}^{2}$ sehingga faktor pembobotnya sebesar 0,29 .

Tabel 1.

Curah Hujan Rata-Rata (mm/15 hari)

\begin{tabular}{|c|c|c|c|c|c|c|c|c|c|c|c|c|}
\hline & \multicolumn{2}{|c|}{ Januari } & \multicolumn{2}{|c|}{ Februari } & \multicolumn{2}{|c|}{ Maret } & \multicolumn{2}{|c|}{ April } & \multicolumn{2}{|c|}{ Mei } & \multicolumn{2}{|c|}{ Juni } \\
\hline & Jan-1 & Jan-2 & Feb-1 & Feb-2 & Mar-1 & Mar-2 & Apr-1 & Apr-2 & Mei-1 & Mei-2 & Jun-1 & Jun-2 \\
\hline 2007 & 51.26 & 43.12 & 9.22 & 183.35 & 6.12 & 184.72 & 187.84 & 236.38 & 94.01 & 150.21 & 7.33 & 107.20 \\
\hline 2008 & 178.44 & 114.52 & 137.78 & 169.54 & 329.19 & 349.57 & 72.12 & 39.45 & 89.32 & 112.60 & 26.69 & 13.90 \\
\hline 2009 & 140.98 & 227.71 & 198.30 & 242.11 & 143.00 & 144.64 & 286.75 & 163.08 & 135.89 & 161.64 & 37.44 & 39.04 \\
\hline 2010 & 268.22 & 197.30 & 201.37 & 154.31 & 198.05 & 315.23 & 98.81 & 225.73 & 192.59 & 289.75 & 122.83 & 103.83 \\
\hline 2011 & 285.53 & 325.93 & 210.58 & 139.24 & 149.00 & 187.85 & 212.87 & 230.24 & 147.57 & 156.97 & 16.44 & 10.01 \\
\hline 2012 & 310.71 & 285.46 & 225.34 & 197.82 & 329.33 & 243.97 & 175.47 & 253.84 & 54.16 & 108.46 & 5.75 & 0.00 \\
\hline 2013 & 240.11 & 224.14 & 7.21 & 223.20 & 107.12 & 208.00 & 88.33 & 185.42 & 107.98 & 159.98 & 146.61 & 191.67 \\
\hline 2014 & 321.30 & 292.89 & 129.17 & 150.10 & 149.99 & 113.40 & 115.49 & 73.43 & 85.38 & 68.12 & 5.08 & 4.86 \\
\hline 2015 & 203.28 & 168.33 & 157.52 & 278.47 & 227.82 & 288.80 & 211.16 & 194.54 & 28.51 & 19.26 & 22.89 & 6.13 \\
\hline 2016 & 194.89 & 127.28 & 341.83 & 197.94 & 151.91 & 243.09 & 255.91 & 153.99 & 144.85 & 168.98 & 138.85 & 345.70 \\
\hline \multirow{2}{*}{ Tahun } & \multicolumn{2}{|c|}{ Juli } & \multicolumn{2}{|c|}{ Agustus } & \multicolumn{2}{|c|}{ September } & \multicolumn{2}{|c|}{ Oktober } & \multicolumn{2}{|c|}{ November } & \multicolumn{2}{|c|}{ Desember } \\
\hline & Jul-1 & Jul-2 & Ags-1 & Ags-2 & Sep-1 & Sep-2 & Okt-1 & Okt-2 & Nov-1 & Nov-2 & Des-1 & Des-2 \\
\hline 2007 & 40.40 & 32.66 & 5.00 & 16.89 & 11.54 & 5.76 & 15.30 & 3.62 & 69.20 & 153.25 & 299.68 & 322.74 \\
\hline 2008 & 7.68 & 13.62 & 11.95 & 24.47 & 8.00 & 7.55 & 157.13 & 203.85 & 188.12 & 241.06 & 118.74 & 194.42 \\
\hline 2009 & 27.58 & 38.35 & 0.75 & 4.02 & 9.18 & 48.67 & 118.04 & 85.37 & 198.87 & 92.73 & 104.85 & 150.82 \\
\hline 2010 & 115.03 & 115.82 & 39.18 & 161.52 & 294.61 & 317.05 & 296.82 & 342.60 & 349.41 & 384.46 & 213.73 & 204.34 \\
\hline 2011 & 16.14 & 18.85 & 0.00 & 0.00 & 25.31 & 13.08 & 108.28 & 48.84 & 319.23 & 230.23 & 210.49 & 93.55 \\
\hline 2012 & 0.00 & 21.84 & 0.00 & lל & 6.12 & 2.24 & 67.07 & 93.36 & 132.37 & 187.41 & 283.57 & 193.79 \\
\hline 2013 & 22.24 & 89.30 & 0.75 & 0.75 & 0.00 & 8.34 & 45.35 & 74.43 & 209.57 & 168.37 & 398.24 & 368.75 \\
\hline 2014 & 17.40 & 27.12 & 7.23 & 24.35 & 0.00 & 0.00 & 4.13 & 4.13 & 273.33 & 180.14 & 315.60 & 346.14 \\
\hline 2015 & 1.89 & 0.00 & 0.00 & 1.72 & 1.39 & 1.39 & 7.44 & 0.56 & 129.64 & 230.23 & 275.13 & 147.44 \\
\hline 2016 & 2.34 & 180.51 & 38 & 80.04 & 3.24 & 108.17 & 2.49 & 205.68 & 3.59 & 30 & 309.60 & \\
\hline
\end{tabular}

\section{B. Analisis Evapotranspirasi}

Data klimatologi diperoleh dari Badan Meteorologi, Klimatologi, dan Geofisika (BMKG) Jembrana. Data yang tercatat yaitu suhu rata-rata bulanan $23{ }^{\circ} \mathrm{C}$ sampai dengan $29^{\circ} \mathrm{C}$. Sedangkan penguapan rata- rata bulanan berkisar antara $2 \mathrm{~mm}$ sampai dengan $11 \mathrm{~mm}$.

Berikut ini contoh perhitungan evapotranspirasi pada bulan Januari (Lily Montarcih Limantara, 2010): 
JURNAL HIDROTEKNIK Vol. 2, No.2, (2017) ISSN : 2477-3212

1. Data klimatologi pada bulan Januari

- Suhu rata-rata $(\mathrm{T}): 28^{\circ} \mathrm{C}$

- LL (Seririt) : $8^{\circ} \mathrm{LS} \rightarrow \mathrm{P}=0.29$

- C : 0.8

2. Perhitungan

$$
\begin{aligned}
-\mathrm{ETo}^{*} & =\mathrm{P}(0.457 \mathrm{t}+8.13) \\
& =0.29(0.457 \times 28+8.13)=6.03 \\
- \text { ETo } & =\mathrm{C} . \text { ETo* } \\
& =0.8 \times 6.03=4.82 \mathrm{~mm} / \mathrm{hari}
\end{aligned}
$$

Tabel 2.

Perhitungan Evapotranspirasi Potensial

\begin{tabular}{|c|c|c|c|c|c|c|c|c|c|c|c|c|}
\hline Bulan & Jan & Feb & Mar & Apr & Mei & Jun & Jul & Agu & Sep & Okt & Nov & Des \\
\hline T & 28 & 27 & 29 & 28 & 28 & 28 & 29 & 28 & 28 & 28 & 28 & 26 \\
\hline P & 0.29 & 0.28 & 0.28 & 0.28 & 0.27 & 0.27 & 0.27 & 0.27 & 0.28 & 0.28 & 0.28 & 0.29 \\
\hline C & 0.8 & 0.8 & 0.75 & 0.7 & 0.7 & 0.7 & 0.7 & 0.75 & 0.8 & 0.8 & 0.8 & 0.8 \\
\hline Eto* & 6.03 & 5.69 & 5.95 & 5.82 & 5.67 & 5.59 & 5.77 & 5.63 & 5.87 & 5.91 & 5.90 & 5.74 \\
\hline Eto (mm/hari) & 4.82 & 4.55 & 4.46 & 4.07 & 3.97 & 3.91 & 4.04 & 4.22 & 4.70 & 4.73 & 4.72 & 4.59 \\
\hline
\end{tabular}

(Sumber : Hasil Perhitungan)

\section{Debit Aliran Rendah}

Berikut ini tahap perhitungan debit tersedia

\section{Metode FJ Mock :}

1. Data Hujan

- Curah Hujan (P)

- Hari Hujan (h)

2. Evapotranspirasi terbatas (Et)

- Evapotranspir potensial (Eto)

- Lahan terbuka, m

- Evapotranspirasi terbatas, Et

$\mathrm{Et}=$ Eto $-($ Eto $\mathrm{x}(\mathrm{m} / 20) \times(18-\mathrm{n})$

3. Keseimbangan air (Water Balance)

- Kandungan Air Tanah, DS = P - Et

- Aliran permukaan hujan lebat, PF x P

- Faktor aliran hujan lebat (PF)

- Kandungan Air tanah, SS = DS - aliran permukaan

- Kapasitas kelembaban tanah, SCM $=150+$ SS

- Kelebihan air, WS = DS

4. Aliran dan Penyimpanan Air Tanah :

- Infiltrasi, I = WS x i

Nilai koefisien infiltasi, $\mathrm{i}$

- 0,5 x (1+k) x In

$\mathrm{k}=$ koefisien resesi infiltrasi

- k x V x (n-1)

- Volume penyimpanan, $\mathrm{Vn}$

$\mathrm{Vn}=\{0,5 \times(1+\mathrm{k}) \times \mathrm{In}\}+\{\mathrm{k} \times \mathrm{V} \times(\mathrm{n}-1)\}$

- Perubahan volume air, $d V n=V n-V n-1$

- Aliran dasar, $\mathrm{BF}=\mathrm{I}-\mathrm{dVn}$

- Aliran langsung, DR = DS - I
- Aliran, R = BF + DR

- Debit Aliran Sungai ( $\left.\mathrm{m}^{3} / \mathrm{dt}\right)$

\begin{tabular}{|c|c|c|c|c|c|c|c|c|c|c|c|c|}
\hline \multirow{2}{*}{ Tahun } & \multicolumn{2}{|c|}{ Januari } & \multicolumn{2}{|c|}{ Februari } & \multicolumn{2}{|c|}{ Maret } & \multicolumn{2}{|c|}{ April } & \multicolumn{2}{|c|}{ Mei } & \multicolumn{2}{|c|}{ Juni } \\
\hline & Jan-1 & Jan-2 & Feb-1 & Feb-2 & Mar-1 & Mar-2 & Apr-1 & Apr-2 & Mei-1 & Mei-2 & Jun-1 & Jun-2 \\
\hline 2007 & 3.47 & 2.81 & 6.70 & 7.92 & 11.68 & 8.53 & 8.95 & 11.39 & 7.40 & 7.11 & 4.22 & 4.70 \\
\hline 2008 & 8.22 & 5.06 & 6.17 & 7.61 & 15.50 & 17.00 & 6.14 & 3.29 & 6.71 & 5.01 & 2.19 & 1.53 \\
\hline 2009 & 6.41 & 10.49 & 9.38 & 11.55 & 6.91 & 6.84 & 13.89 & 8.12 & 6.78 & 7.86 & 3.00 & 2.66 \\
\hline 2010 & 12.58 & 9.39 & 9.67 & 7.37 & 9.49 & 15.20 & 8.11 & 11.10 & 9.66 & 14.41 & 6.45 & 5.29 \\
\hline 2011 & 13.45 & 15.69 & 10.53 & 7.03 & 7.34 & 9.06 & 10.45 & 11.39 & 7.52 & 7.79 & 2.50 & 1.91 \\
\hline 2012 & 14.64 & 13.80 & 11.21 & 9.91 & 16.29 & 12.45 & 9.31 & 12.95 & 4.88 & 5.47 & 2.10 & 1.55 \\
\hline 2013 & 11.24 & 10.59 & 10.98 & 10.85 & 5.26 & 9.90 & 6.93 & 8.83 & 5.11 & 7.48 & 6.91 & 9.08 \\
\hline 2014 & 15.18 & 14.20 & 6.57 & 7.27 & 7.22 & 5.26 & 5.37 & 5.31 & 6.08 & 4.56 & 1.22 & 1.00 \\
\hline 2015 & 11.40 & 7.87 & 7.39 & 13.24 & 11.09 & 14.16 & 10.78 & 9.99 & 3.26 & 2.50 & 2.22 & 1.42 \\
\hline 2016 & 9.05 & 5.75 & 16.22 & 9.68 & 7.39 & 11.75 & 12.70 & 7.86 & 7.36 & 8.36 & 6.89 & 16.92 \\
\hline \multirow{2}{*}{ Tahun } & \multicolumn{2}{|c|}{ Juli } & \multicolumn{2}{|c|}{ Agustus } & \multicolumn{2}{|c|}{ September } & \multicolumn{2}{|c|}{ Oktober } & \multicolumn{2}{|c|}{ November } & \multicolumn{2}{|c|}{ Desember } \\
\hline & Jul-1 & Jul-2 & Ags-1 & Ags-2 & Sep-1 & Sep-2 & Okt-1 & Okt-2 & Nov-1 & Nov-2 & Des-1 & Des-2 \\
\hline 2007 & 2.51 & 2.02 & 1.00 & 1.18 & 0.88 & 0.61 & 0.80 & 0.39 & 3.23 & 5.30 & 12.84 & 14.55 \\
\hline 2008 & 1.13 & 1.12 & 0.93 & 1.18 & 0.60 & 0.52 & 5.49 & 8.03 & 7.65 & 10.47 & 4.87 & 8.53 \\
\hline 2009 & 2.02 & 2.09 & 0.80 & 0.74 & 0.77 & 1.86 & 3.69 & 4.74 & 7.83 & 5.67 & 3.54 & 5.79 \\
\hline 2010 & 5.47 & 5.38 & 2.76 & 7.05 & 13.41 & 14.89 & 14.33 & 16.82 & 17.51 & 19.56 & 11.54 & 10.85 \\
\hline 2011 & 1.76 & 1.59 & 0.83 & 0.66 & 1.27 & 0.81 & 3.21 & 1.89 & 13.54 & 9.91 & 9.30 & 6.55 \\
\hline 2012 & 1.24 & 1.63 & 0.79 & 0.71 & 0.69 & 0.76 & 3.16 & 5.23 & 4.47 & 7.32 & 12.37 & 8.51 \\
\hline 2013 & 2.39 & 6.35 & 1.27 & 1.02 & 0.80 & 0.88 & 1.84 & 3.83 & 8.23 & 6.60 & 18.20 & 17.52 \\
\hline 2014 & 1.19 & 1.34 & 0.65 & 1.06 & 0.28 & 0.22 & 0.30 & 0.26 & 11.07 & 7.15 & 14.04 & 16.14 \\
\hline 2015 & 1.05 & 0.79 & 0.64 & 0.56 & 0.45 & 0.37 & 0.48 & 0.22 & 4.12 & 9.23 & 11.93 & 6.21 \\
\hline 2016 & 6.35 & 8.96 & 2.80 & 5.82 & 8.04 & 4.43 & 12.31 & 9.38 & 13.57 & 14.82 & 15.25 & 20.42 \\
\hline
\end{tabular}

Debit aliran sungai $=$ Luas DAS x Aliran Tabel 3.

Rekapitulasi Debit Aliran Rendah

\section{Analisis Bangkitan Debit Inflow}

Dari hasil perhitungan debit bangkitan selama 30 tahun ke depan menggunakan metode Thomas Fiering dibuat grafik debit seperti berikut :

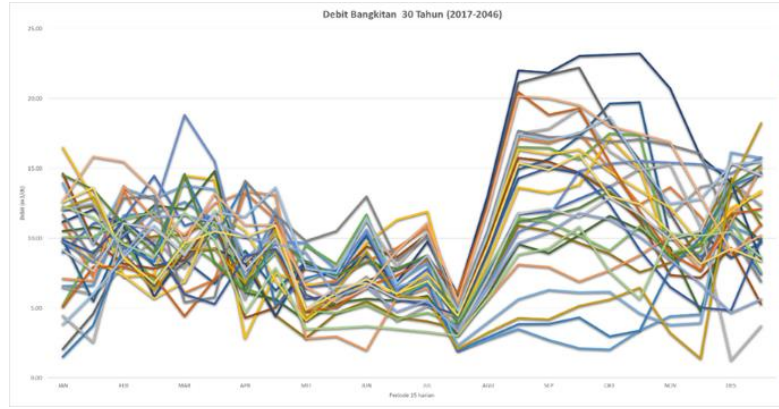

Gambar 4. Fluktuasi Debit Bangkitan 30 Tahun. (Sumber : Hasil Perhitungan)

\section{E. Perhitungan Hujan Efektif}

1. Mengurutkan data curah hujan efektif.

2. Menghitung Curah Hujan efektif dengan peluang keandalan $80 \%$

$$
\begin{array}{r}
-\mathrm{R} 80=(\mathrm{n} / 5)+1 \\
\mathrm{n}=\text { jumlah data }
\end{array}
$$

3. Dari data curah hujan yang telah diurutkan didapatkan 3 peringkat terbawah sebagai R80 nya

4. Menghitung curah hujan efektif, Re tiap jenis tanaman :

- Repadi $=($ R80 x 70\% $) / 10$

- Re polowijo : $50 \% \mathrm{R} 80$ 
JURNAL HIDROTEKNIK Vol. 2, No.2, (2017) ISSN : 2477-3212

- Repolowijo $=\mathrm{fD}\left(1,25 \times \mathrm{R}_{50} 0,824-2,93\right) \times$ $10^{0,00095 . E t o}$

${ }^{-} \mathrm{fD}=0,53+\left(0,00016 \times 10^{-5} \times 0^{2}\right)+(2,32$ $\left.\mathrm{x} 10^{-7} \times 100^{3}\right)=0,76$

- Re anggur :60\% R80

Reanggur $=\mathrm{fD}\left(1,25 \times \mathrm{R} 50^{0,824}-2,93\right) \times$ $10^{0,00095 . E t o}$

- $\mathrm{fD}=0,53+\left(0,00016 \times 10^{-5} \times 0^{2}\right)+(2,32$ $\left.\mathrm{x} 10^{-7} \times 100^{3}\right)=0,76$

Tabel 4.

Perhitungan Hujan Efektif Tanaman

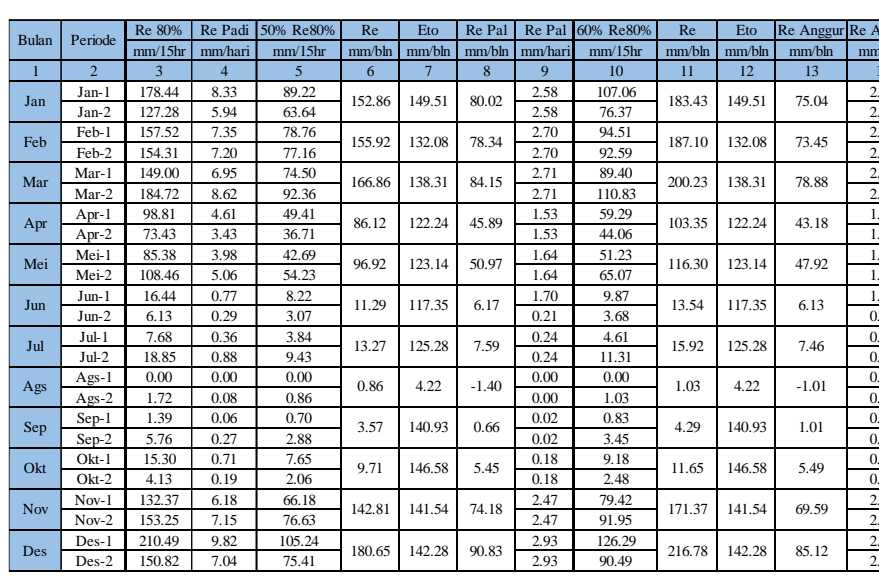

\section{F. Kebutuhan Air Penyiapan Lahan}

Berikut ini adalah hasil dari perhitungan kebutuhan air penyiapan lahan :

Tabel 5.

Perhitungan Kebutuhan Air Penyiapan Lahan

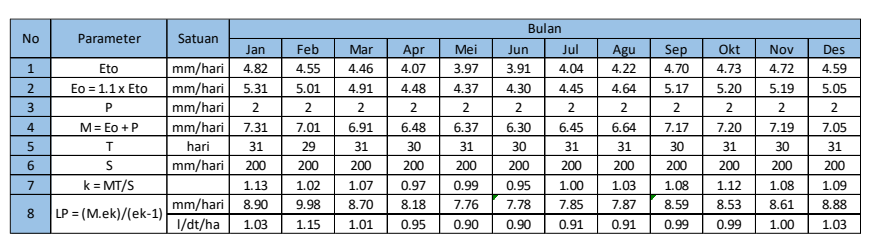

\section{G. Perencanaan Pola Tanam}

Musim tanam pada studi ini adalah sebagai berikut :

1. Musim Tanam Hujan : November - Februari

2. Musim Tanam Kemarau I: Maret - Juni

3. Musim Tanam Kemarau II : Juli-Oktober

Alternatif pola tanam pada studi optimasi adalah sebagai berikut :

1. Alternatif 1 : Awal masa tanam pada bulan Nopember I

2. Alternatif 2 : Awal masa tanam pada bulan Nopember II

3. Alternatif 3 : Awal masa tanam pada bulan Desember I
4. Alternatif 4 : Awal masa tanam pada bulan Desember II

5. Alternatif 5 : Awal masa tanam pada bulan Januari I

6. Alternatif 6 : Awal masa tanam pada bulan Januari II

Berikut ini adalah tabel contoh perhitungan kebutuhan air tanaman :

Tabel 6.

Perhitungan Kebutuhan Air Tanaman Awal Masa Tanam Nopember I D.I. Saba

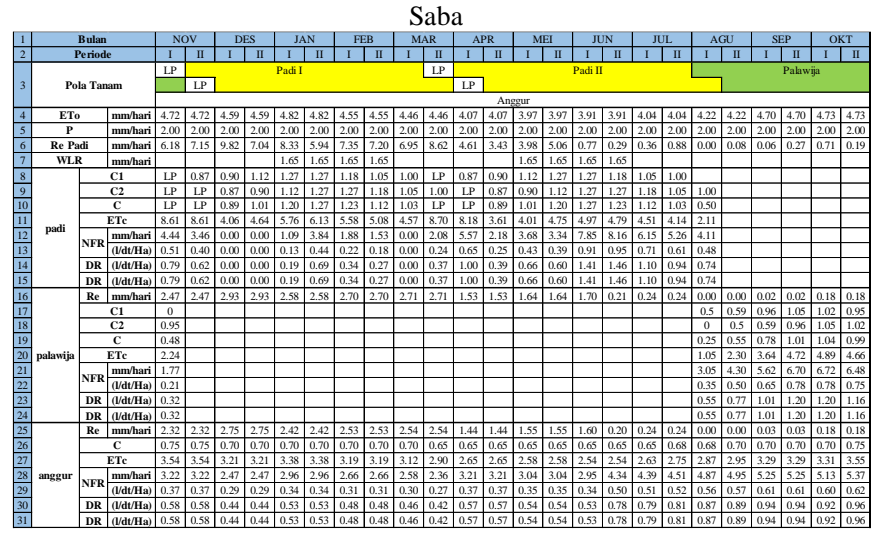

\section{H. Analisa Kebutuhan Air Baku}

Berikut ini adalah hasil perhitungan kebutuhan air baku untuk kecamatan Busungbiu, kecamatan Seririt, dan kecamatan Banjar untuk tahun 20162046

Tabel 7.

Jumlah Total Kebutuhan Air Baku

\begin{tabular}{|c|c|c|c|c|c|c|c|}
\hline \multirow{2}{*}{ Tahun } & NORMAL & FHM (1.15) & FJP (1.75) & \multirow{2}{*}{ Tahun } & NORMAL & FHM (1.15) & FJP (1.75) \\
\cline { 2 - 5 } & It/detik & It/detik & It/detik & & It/detik & It/detik & It/detik \\
\hline 2016 & 430.31 & 494.85 & 753.04 & 2031 & 499.56 & 574.50 & 874.23 \\
\hline 2017 & 434.52 & 499.70 & 760.41 & 2032 & 504.67 & 580.37 & 883.17 \\
\hline 2018 & 438.79 & 504.61 & 767.88 & 2033 & 509.84 & 586.32 & 892.23 \\
\hline 2019 & 443.11 & 509.58 & 775.45 & 2034 & 515.08 & 592.35 & 901.40 \\
\hline 2020 & 447.49 & 514.62 & 783.11 & 2035 & 520.39 & 598.45 & 910.69 \\
\hline 2021 & 451.93 & 519.72 & 790.88 & 2036 & 525.77 & 604.63 & 920.09 \\
\hline 2022 & 456.42 & 524.89 & 798.74 & 2037 & 531.21 & 610.90 & 929.62 \\
\hline 2023 & 460.97 & 530.12 & 806.70 & 2038 & 536.73 & 617.24 & 939.28 \\
\hline 2024 & 465.58 & 535.42 & 814.77 & 2039 & 542.32 & 623.66 & 949.06 \\
\hline 2025 & 470.25 & 540.79 & 822.94 & 2040 & 547.98 & 630.17 & 958.96 \\
\hline 2026 & 474.98 & 546.23 & 831.22 & 2041 & 553.71 & 636.77 & 968.99 \\
\hline 2027 & 479.77 & 551.74 & 839.60 & 2042 & 559.52 & 643.44 & 979.15 \\
\hline 2028 & 484.63 & 557.32 & 848.09 & 2043 & 565.40 & 650.21 & 989.44 \\
\hline 2029 & 489.54 & 562.97 & 856.70 & 2044 & 571.35 & 657.06 & 999.87 \\
\hline 2030 & 494.52 & 568.70 & 865.41 & 2045 & 577.39 & 664.00 & 1010.43 \\
\hline & & & & 2046 & 583.50 & 671.02 & 1021.12 \\
\hline
\end{tabular}


JURNAL HIDROTEKNIK Vol. 2, No.2, (2017) ISSN : 2477-3212

\section{Analisis Potensi PLTA}

1. Berdasarkan duration curve didapatkan: $\mathrm{Q} 80=$ $1,55 \mathrm{~m}^{3} / \mathrm{dt}$

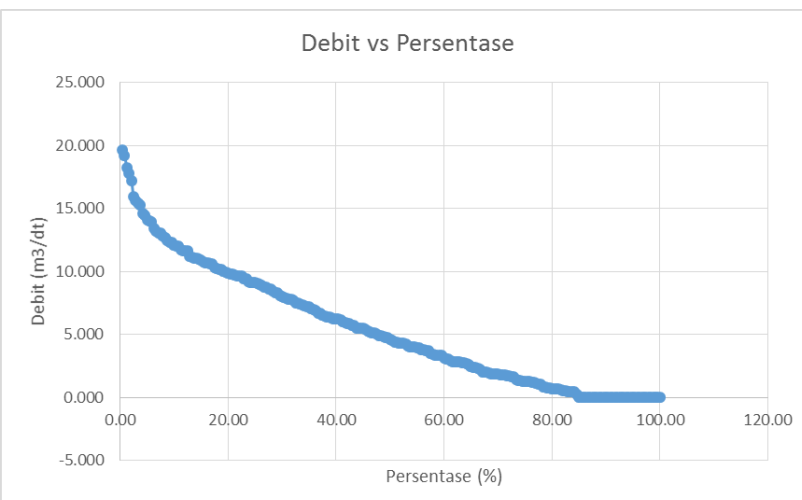

Gambar 5. Duration Curve

\section{Tinggi Jatuh Efektif, Heff}

Tinggi jatuh efektif didapat dari selisih elevasi permukaan air di upstream dan di downstream

- Elevasi upstream $=+162,40 \mathrm{~m}$

- Elevasi downstream $=+102,50 \mathrm{~m}$

- Heff bruto $=$ elv. upstream - elv. downstream

- Heff bruto $=(+162,40)-(+102,50)=$ $59,90 \mathrm{~m}$

- Heff losses $=10 \% \mathrm{x}$ Heff bruto $=0,1 \mathrm{x}$ $59,90=5,99 \mathrm{~m}$

- Heff $=$ Heff bruto - Heff losses $\quad=59,90-$ $5,99=53,91 \mathrm{~m}$

- Tekanan maksimal $10 \%$ dari Head bruto (Patty, 1995)

\section{Pemilihan Jenis Turbin}

Berdasarkan grafik Turbin Selection (Gambar 4.5). Turbin yang dipilih dengan besar debit air $1,55 \mathrm{~m}^{3} /$ detik dan tinggi jatuh efektif $53,91 \mathrm{~m}$ adalah turbin Francis. Pemilihan ini dipengaruhi juga karena pengoperasiannya yang mudah. Adapun Spesifikasi dari Turbin Francis :

- Efisiensi turbin, $\eta=91 \%=0,91$

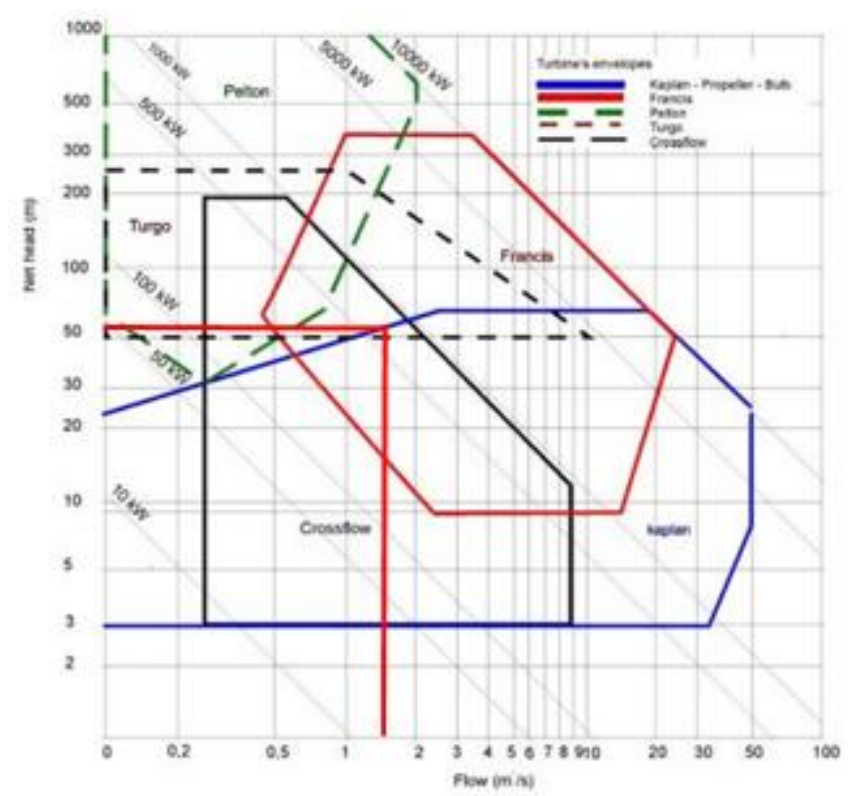

Gambar 6. Pemilihan Jenis Turbin

\section{Tabel 8.}

Hubungan jenis turbin dengan berbagai variasi head

\begin{tabular}{|c|c|}
\hline Jenis Turbin & Variasi Head $(\mathbf{m})$ \\
\hline Kaplan dan Propeller & $2<\mathrm{H}<40$ \\
\hline Francis & $10<\mathrm{H}<350$ \\
\hline Pelton & $50<\mathrm{H}<1300$ \\
\hline Crossflow & $3<\mathrm{H}<250$ \\
\hline Turgo & $50<\mathrm{H}<250$ \\
\hline
\end{tabular}

4. Daya Listrik

$$
\begin{aligned}
-\mathrm{P} & =\eta \times \mathrm{g} \times \text { Heff } \times \mathrm{Q} \\
-\mathrm{P} 80 & =91 \% \times 9,8 \times 55,8 \times 1,55=743,22 \mathrm{~kW} \\
& =0,74 \mathrm{MW}
\end{aligned}
$$

5. Energi Listrik $\mathrm{E}=\mathrm{P} \times \mathrm{t}$

$$
\begin{aligned}
-\mathrm{E} 80 & =743,22 \mathrm{~kW} \times 365 \text { hari } \times 24 \mathrm{jam} \\
& =6510607,92 \mathrm{kWh}=6510,61 \mathrm{MWh}
\end{aligned}
$$

\section{J. Analisis Simulasi Pola Operasi Waduk}

Berikut ini adalah tabel contoh water balance awal masa tanam Nopember I dengan luas daerah irigasi optimasi : 
JURNAL HIDROTEKNIK Vol. 2, No.2, (2017) ISSN : 2477-3212

Tabel 9.

Perhitungan analisis Water Balance waduk pola tanam Nopember I tahun ke-1.

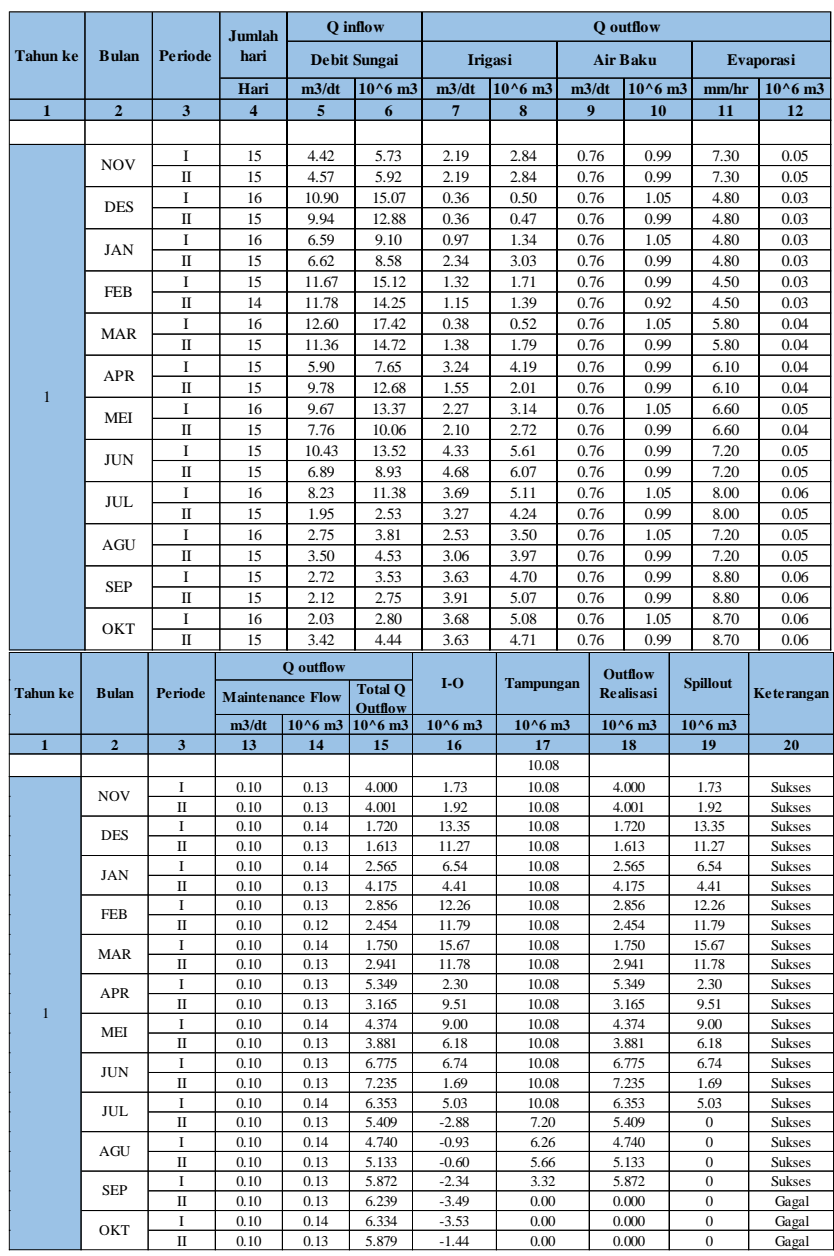

Dari perhitungan water balance diperoleh rasio keberhasilan waduk dalam memenuhi kebutuhan yaitu mencapai 99,44\%. Kemudian dibuat tiga buah grafik yang menunjukkan keadaan air pada waduk. Berikut ini adalah contoh grafik pada tahun ke 1-5 :

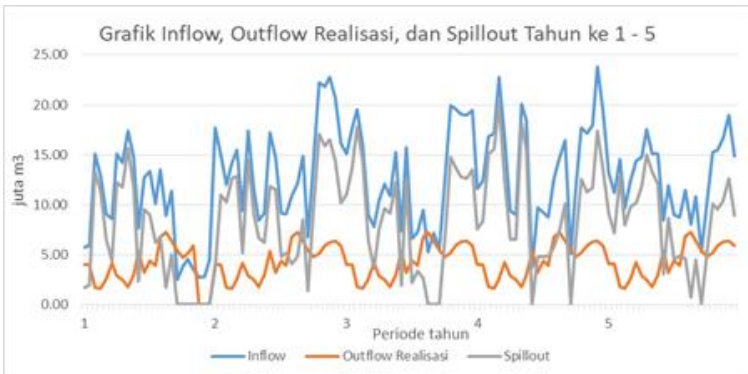

Gambar 7. Grafik Inflow, Outflow Realisasi, dan Spillout tahun ke 1-5

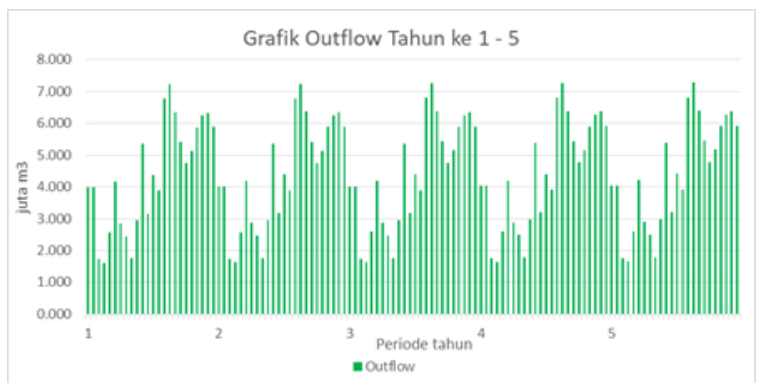

Gambar 8. Grafik Outflow tahun ke 1-5

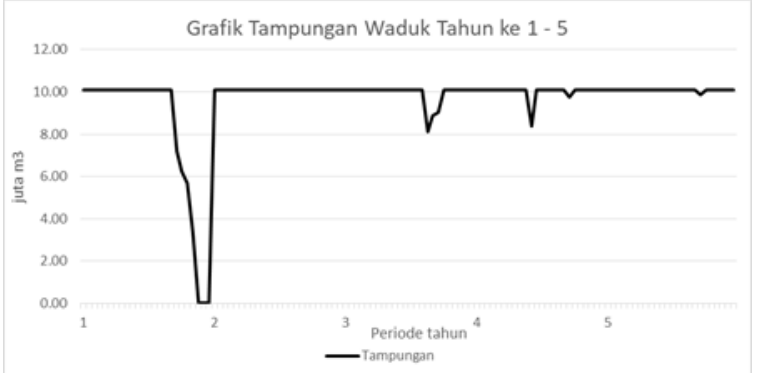

Gambar 9. Grafik Tampungan Waduk tahun ke 1-5

\section{K. Perbandingan Perencanaan Simulasi}

Hasil dari pelaksanaan studi ini yaitu perbandingan antara perhitungan perencanaan simulasi pola operasi yang sudah ada (eksisting) dengan hasil perhitungan perencanaan alternatif pola operasi dari tugas akhir ini. Perbandingan hasil perhitungan tersebut ditampilkan pada tabel 5.3.

Tabel 10.

Perbandingan perencanaan eksisting dan hasil studi

\begin{tabular}{|c|c|c|}
\hline $\begin{array}{c}\text { Aspek } \\
\text { Perbandingan }\end{array}$ & Eksisting & Hasil studi \\
\hline Debit andalan & $\begin{array}{l}\text { Debit } 15 \text { harian bendung saba tahun } \\
1988-2003 \text { ( } 16 \text { tahun). Debit terbesar } \\
\text { adalah } 28,07 \mathrm{~m} 3 / \mathrm{dt} \text {, debit terkecil adalah } \\
0 \mathrm{~m} 3 / \mathrm{dt}\end{array}$ & $\begin{array}{l}\text { Perhitungan debit andalan dengan data } \\
\text { hujan } 15 \text { harian tahum } 2007-2016 \text { (10 } \\
\text { tahun) menggunakan metode mock } \\
\text { dengan debit terbesar adalah } 20,42 \mathrm{~m} 3 / \mathrm{dt} \\
\text { dan debit terkecil adalah } 0,22 \mathrm{~m} 3 / \mathrm{dt}\end{array}$ \\
\hline & \multicolumn{2}{|c|}{ Kebutuhan air maksimum di intake (DR) } \\
\hline $\begin{array}{c}\text { Air irigasi } \\
\text { (Jan I dan Jan II) }\end{array}$ & $\begin{array}{l}\text { 1. Luas daerah irigasi } 1794,82 \text { heltar } \\
\text { Januari I } \\
\text { D.I. Saba : } 2,61 \mathrm{~m}^{3} / \mathrm{dt} \\
\text { D.I. Puluran : } 0,73 \mathrm{~m}^{3} / \mathrm{dt} \\
\text { Januari II } \\
\text { D.I. Saba : } 2,75 \mathrm{~m}^{3} / \mathrm{dt} \\
\text { D.I. Puluran : } 0,76 \mathrm{~m}^{3} / \mathrm{dt}\end{array}$ & $\begin{array}{l}\text { 1. Luas daerah irigasi } 1794,82 \text { hehtar } \\
\text { - Januari I } \\
\text { D.I. Saba : } 2,24 \mathrm{~m}^{3} / \mathrm{dt} \\
\text { D.I. Puluran : } 0,57 \mathrm{~m}^{3} / \mathrm{dt} \\
\text { - Januari II } \\
\text { D.I. Saba : } 2,45 \mathrm{~m}^{3} / \mathrm{dt} \\
\text { D.I. Puluran : } 0,59 \mathrm{~m}^{3} / \mathrm{dt} \\
\text { 2. Luas daerah irigasi } 3589,64 \text { heltar } \\
\text { - Januari I } \\
\text { D.I. Saba : }: 4,47 \mathrm{~m}^{3} / \mathrm{dt} \\
\text { D.. Puluran : } 1,14 \mathrm{~m}^{3} / \mathrm{dt} \\
\text { - Januari II } \\
\text { D.I. Saba : } 4,84 \mathrm{~m}^{3} / \mathrm{dt} \\
\text { D.I. Puluran : } 1,19 \mathrm{~m}^{3} / \mathrm{dt}\end{array}$ \\
\hline $\begin{array}{c}\text { Air baku } \\
\text { (tahun 2043) }\end{array}$ & $\begin{array}{l}\text { Kondisi normal }=312,44 \mathrm{lt} / \mathrm{dt} \\
\text { Kondisi hari maksimum }=364,30 \mathrm{lt} / \mathrm{dt} \\
\text { Kondisi jam puncak }=494,17 \mathrm{lt} / \mathrm{dt}\end{array}$ & 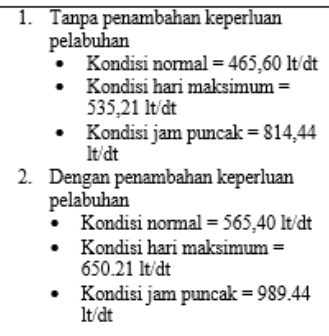 \\
\hline PLTA & Kapasitas terpasang $=2 \times 0,75 \mathrm{MW}$ & 1 turbin $=0,74 \mathrm{MW}$ \\
\hline Simulasi & Tingkat keberhasilan rata-rata $96,50 \%$ & $\begin{array}{l}\text { Tingkat keberhasilan rata-rata sebelum } \\
\text { optimasi } 100 \% \\
\text { Tingkat keberhasilan rata-rata setelah } \\
\text { optimasi } 98,50 \%\end{array}$ \\
\hline
\end{tabular}


JURNAL HIDROTEKNIK Vol. 2, No.2, (2017) ISSN : 2477-3212

\section{KESIMPULAN}

1. Hasil dari bangkitan debit inflow, yaitu debit maksimal sebesar 23,23 $\mathrm{m}^{3} /$ detik dan debit terendah adalah $1,28 \mathrm{~m}^{3} /$ detik. Untuk debit outflow maksimal sebesar $6,24 \mathrm{~m}^{3} /$ detik dan debit terendah sebesar $3,55 \mathrm{~m}^{3} /$ detik.

2. Besar kebutuhan air irigasi maksimum untuk awal masa tanam Nopember I dengan luas daerah irigasi 3589,64 Ha D.I. Saba adalah $3,66 \mathrm{~m}^{3} /$ detik dan minimum sebesar 0,27 $\mathrm{m}^{3} /$ detik. Untuk daerah irigasi puluran kebutuhan maksimum sebesar $1,02 \mathrm{~m}^{3} /$ detik dan minimum sebesar $0,09 \mathrm{~m}^{3} /$ detik.

3. Besar kebutuhan air baku untuk tahun 20172046 pada keadaan normal adalah sebesar 583,50 lt/dt. Sedangkan besar kebutuhan air baku pada hari maksimum adalah sebesar $671,02 \mathrm{lt} / \mathrm{dt}$. Untuk jam puncak adalah sebesar $1021,12 \mathrm{lt} / \mathrm{dt}$.

4. Besar debit Andalan $80 \%$ yang digunakan adalah sebesar $1.55 \mathrm{~m}^{3} /$ detik untuk digunakan perhitungan potensi PLTA dan dapat membangkitkan daya sebesar 0,74 MW, serta energi listrik hingga mencapai 6510,61 MWh.

5. Dari hasil perbandingan yang telah dibuat, dapat diketahui bahwa alternatif yang lebih baik adalah perhitungan perencanaan simulasi pola operasi hasil studi. Alasan dari penilaian ini adalah perencanaan hasil studi dilakukan setelah waduk sudah selesai dibangun, sudah dilakukan optimasi kebutuhan air yang diperlukan, dan tingkat keberhasilan waduk dari perencanaan studi yaitu rata-rata sebesar 98,50\% yang mana tingkat keberhasilan tersebut lebih besar dari perencanaan pada eksisting.

\section{DAFTAR PUSTAKA}

[1] Badan Pusat Statistik Buleleng. 2017. Buleleng Dalam Angka. Buleleng : Badan Pusat Statistik.

[2] Balai Besar Wilayah Sungai Bali Penida. 2015. Data Teknis Waduk Titab. Denpasar : Balai Besar Wilayah Bali Penida.

[3] Departemen Pekerjaan Umum Pengairan. 1986. Standar Perencanaan Irigasi KP 01. Bandung : CV Galang Persada.

[4] Limantara, Lily Montarcih. 2010. Hidrologi

Praktis. Bandung: Lubuk Agung.
[5] Nusantara, Danayanti Azmi Dewi. 2016. Perencanaan PLTA. Bahan Ajar. Surabaya : Program S1 Departemen Tenik Sipil ITS.

[6] Soemarto, CD. 1987. Hidrologi Teknik. Jakarta : Penerbit Usaha Nasional. 